\title{
Effects of partly replacing dietary starch with fiber and fat on milk production and energy partitioning
}

\author{
J. P. Boerman, S. B. Potts, M. J. VandeHaar, and A. L. Lock ${ }^{1}$ \\ Department of Animal Science, Michigan State University, East Lansing 48824
}

\begin{abstract}
The effects of partly replacing dietary starch with fiber and fat to provide a diet with similar net energy for lactation $\left(\mathrm{NE}_{\mathrm{L}}\right)$ density on yields of milk and milk components and on energy partitioning were evaluated in a crossover design experiment. Holstein cows $(\mathrm{n}=$ $32 ; 109 \pm 22 \mathrm{~d}$ in milk, mean \pm standard deviation) were randomly assigned to treatment sequence. Treatments were a high-starch diet containing $33 \%$ corn grain (mixture of dry ground and high-moisture corn; HS) or a high-fiber, high-fat diet containing $2.5 \%$ palmitic acid-enriched fatty acid (FA) supplement (HFF). Diets contained corn silage, alfalfa silage, and wheat straw as forage sources; HS contained $32 \%$ starch, $3.2 \% \mathrm{FA}$, and $25 \%$ neutral detergent fiber, whereas HFF contained $16 \%$ starch, $5.4 \% \mathrm{FA}$, and $33 \%$ neutral detergent fiber. Compared with HS, the HFF treatment reduced milk yield, milk protein concentration, and milk protein yield, but increased milk fat concentration, milk fat yield, milk energy output, and milk to feed ratio (energycorrected milk/dry matter intake). The HFF treatment reduced the yield of de novo synthesized ( $<16$-carbon) milk FA and increased the yield of 16-carbon milk FA. Yield of preformed ( $>16$-carbon) milk FA was not different. The HFF treatment increased plasma concentrations of triglycerides and nonesterified fatty acids, but decreased plasma concentration of insulin. Compared with HS, the HFF treatment reduced body weight gain, change in body condition score, and fat thickness over the rump and rib. Calculated body energy gain, as a fraction of $\mathrm{NE}_{\mathrm{L}}$ use, was less for HFF than HS, whereas milk energy as a fraction of $\mathrm{NE}_{\mathrm{L}}$ use was increased for HFF. We concluded that the 2 treatments resulted in similar apparent $\mathrm{NE}_{\mathrm{L}}$ densities and intakes, but the $\mathrm{HS}$ treatment partitioned more energy toward body gain whereas the HFF treatment partitioned more energy toward milk. A high-fiber, high-fat diet might diminish
\end{abstract}

Received February 13, 2015.

Accepted May 18, 2015.

${ }^{1}$ Corresponding author: allock@msu.edu the incidence of over conditioning in mid-lactation cows while maintaining high milk production.

Key words: energy partitioning, diet fatty acid concentration, diet starch concentration, feed efficiency, fatty acid digestibility

\section{INTRODUCTION}

In established lactation, cows are usually in positive energy balance and the goals are to maximize milk and component yields and reduce excessive conditioning. During milk fat depression (MFD), there is a decreased priority for milk production and an increased priority for storage of energy as adipose (Van Soest, 1963; Griinari and Bauman, 2006). Therefore, diets that cause MFD result in decreased FCM yield per unit of feed. As a result, diet-induced MFD is detrimental in the short term because of decreased milk income over feed costs and may have negative effects in the long term because of condition gain and health problems associated with excessively conditioned cows. Cows that gain excessive body condition in mid- and late lactation are at high risk for culling in the subsequent lactation due to increased incidence of metabolic diseases and reproductive failure (NRC, 2001; Roche et al., 2009).

In studies comparing high-starch to high-fat diets, the higher-fat diets partitioned more energy toward milk, whereas the higher-starch diets had reduced milk fat output and increased BW (Grum et al., 1996; van Knegsel et al., 2007a). In both studies, increased dietary starch resulted in higher plasma insulin concentrations, and it is well established that insulin inhibits lipid mobilization and stimulates lipogenesis in adipose tissue (Bauman, 2000). Additionally, milk fat synthesis is reduced by specific FA intermediates produced in the rumen by altered rumen biohydrogenation (Bauman et al., 2011). Increasing dietary starch, due to or independent of reduced rumen $\mathrm{pH}$, can increase the formation of biohydrogenation intermediates associated with MFD (Bauman et al., 2011). Specifically, trans10,cis-12 C18:2 has been shown to reduce gene expression of lipogenic enzymes in the mammary gland while upregulating lipogenic gene expression in adipose tissue (Harvatine et al. 2009). Therefore, increased rumen 
synthesis and outflow of trans-10,cis-12 C18:2 can alter the partitioning of energy from the mammary gland to adipose tissue.

Previous studies comparing high-starch to highfat diets were in lower-producing $(<30 \mathrm{~kg} / \mathrm{d}$ of milk production; Grum et al., 1996) or early-lactation (van Knegsel et al., 2007a) cows, whereas our interest is in production responses to diets differing in starch, NDF, and fat in postpeak, higher-producing cows. Our objectives, therefore, were to quantify the effect of diets designed to alter milk fat yield on production, BW gain, body condition, and feed efficiency. Our hypothesis was that postpeak cows fed a high-starch versus a highfiber, high-fat diet would allocate more energy toward body gain due to reductions in milk fat yield through the production of biohydrogenation intermediates or increased plasma insulin concentration that reduce milk fat synthesis and increase adipose tissue gain.

\section{MATERIALS AND METHODS}

\section{Design and Treatments}

The Institutional Animal Care and Use Committee at Michigan State University approved experimental procedures. Thirty-two postpeak Holstein cows (109 \pm 22 DIM, mean \pm SD; range $=64-142$ DIM; 16 primiparous, 16 multiparous) with a wide range in milk yield $(31-65 \mathrm{~kg} / \mathrm{d})$ were selected from the Michigan State University Dairy Field Laboratory and fed a common diet for a minimum of $14 \mathrm{~d}$. Production data were collected the last $3 \mathrm{~d}$ of the preliminary period for covariate values. Cows were blocked by milk yield and parity and then randomly assigned to treatment sequence in a crossover design experiment with 28-d periods. Samples were taken throughout the period for calculations of energy gain and partitioning, but only samples collected during the final $5 \mathrm{~d}$ of each experimental period were used for production measurements, digestibility, and plasma metabolites and hormones.

Treatments consisted of a high-fiber, high-fat diet (HFF) containing a 50:50 ratio of forage to concentrate containing a C16:0-enriched FA supplement at $2.5 \%$ of diet DM or a high-starch diet (HS) containing a 40:60 ratio of forage to concentrate containing a mixture of dry ground and high-moisture corn. The ingredient and nutrient composition of the diets fed as TMR are described in Table 1. Although the diets differed in nutrient composition, they were formulated to contain a similar predicted energy density according to NRC (2001). Mineral and vitamins were formulated according to NRC (2001) recommendations. Dry matter concentration was determined twice weekly for forages, and diets were adjusted when necessary. All cows
Table 1. Diet ingredients and nutrient composition of treatment diets ${ }^{1}$

\begin{tabular}{lcc}
\hline & \multicolumn{2}{c}{ Treatment } \\
\cline { 2 - 3 } Item & HFF & HS \\
\hline Ingredient (\% of DM) & & \\
Corn silage & 24.0 & 24.0 \\
Alfalfa silage & 24.0 & 12.0 \\
Wheat straw & 2.00 & 4.00 \\
Soybean meal & 14.5 & 16.0 \\
Soybean hulls & 10.5 & - \\
Corn grain, high moisture & 10.0 & 20.0 \\
Corn grain, dry ground & - & 13.0 \\
Cottonseed & 9.00 & 7.50 \\
C16:0-enriched FA supplement ${ }^{2}$ & 2.50 & - \\
Vitamin and mineral mix ${ }^{3}$ & 2.00 & 2.00 \\
Limestone & 0.75 & 0.75 \\
Sodium bicarbonate & 0.75 & 0.75 \\
Forage:concentrate & $50: 50$ & $40: 60$ \\
Nutrient composition (\% of DM) & & \\
DM ${ }^{4}$ & 51.6 & 55.8 \\
NDF & 32.8 & 25.1 \\
Forage NDF & 20.2 & 17.6 \\
CP & 18.3 & 17.0 \\
Starch & 16.1 & 32.5 \\
FA & 5.36 & 3.19 \\
16-carbon FA & 2.66 & 0.51 \\
18-carbon FA & 2.39 & 2.46 \\
\hline
\end{tabular}

${ }^{1}$ Experimental diets fed to 32 cows in a crossover design with $28-\mathrm{d}$ periods. HFF $=$ high-fiber, high-fat diet; HS = high-starch diet.

${ }^{2}$ BergaFat F-100 (Berg + Schmidt America LLC, Libertyville, IL).

${ }^{3}$ Vitamin and mineral mix contained $34.1 \%$ dry ground shell corn, $25.6 \%$ white salt, $21.8 \%$ calcium carbonate, $9.1 \%$ Biofos (The Mosaic Co., Plymouth, MN), $3.9 \%$ magnesium oxide, $2 \%$ soybean oil, and $<1 \%$ of each of the following: manganese sulfate, zinc sulfate, ferrous sulfate, copper sulfate, iodine, cobalt carbonate, vitamin E, vitamin A, vitamin $\mathrm{D}$, and selenium.

${ }^{4}$ Expressed as percent of as fed.

were housed in the same tiestall (assigned randomly) throughout the entire experiment and milked twice daily $(0500$ and $1600 \mathrm{~h})$. Access to feed was blocked from 1000 to $1200 \mathrm{~h}$ to allow for collection of orts and offering of new feed. Cows were fed $115 \%$ of expected intake at $1200 \mathrm{~h}$ daily. Water was available ad libitum in each stall, and stalls were bedded with sawdust and cleaned twice daily.

\section{Data and Sample Collection}

Samples and data for production variables, digestibility, and plasma metabolites and hormones were collected during the last $5 \mathrm{~d}$ of each treatment period (d 24-28). Samples of all diet ingredients $(0.5 \mathrm{~kg})$ and orts from each cow (12.5\%) were collected daily and composited by period for analysis. Milk yield was recorded and 2 milk samples were collected at each milking. One aliquot was collected in a sealed tube with preservative (bronopol tablet; D\&F Control Systems, San Ramon, $\mathrm{CA}$ ) and stored at $4^{\circ} \mathrm{C}$ for milk component analysis. 
The second aliquot was stored without preservative at $-20^{\circ} \mathrm{C}$ until analyzed for FA composition.

Fecal ( $\sim 400 \mathrm{~g})$ and blood $(\sim 15 \mathrm{~mL})$ samples were collected every $15 \mathrm{~h}$ for the last $5 \mathrm{~d}$ of each period, resulting in 8 samples per cow per period, representing every $3 \mathrm{~h}$ of a 24-h period to account for diurnal variation. Feces were stored in a sealed plastic cup at $-20^{\circ} \mathrm{C}$ until dried and composited on equal DM basis for each cow period. Blood was collected by coccygeal venipuncture into 3 evacuated tubes; 2 contained potassium EDTA as an anticoagulant and the other contained potassium oxalate as an anticoagulant and sodium fluoride as a glycolytic inhibitor. Blood was stored on ice until centrifugation at $2,000 \times g$ for $15 \mathrm{~min}$ at $4^{\circ} \mathrm{C}$ (within $30 \mathrm{~min}$ of sample collection). Plasma was transferred into microcentrifuge tubes and stored at $-20^{\circ} \mathrm{C}$ until composited by cow period.

On the last day of the preliminary period and last day of each treatment period, subcutaneous fat thickness was determined at 2 locations: the 12th intercostal space and the sacral region between the tuber coxae (hooks) and tuber ischia (pins) via ultrasound (Aloka SSD-500V Ultrasound equipped with a 172-mm Linear Body Composition Transducer (Hitachi Aloka Medical Ltd., Wallingford, CT). The National Centralized Ultrasound Processing Lab (Ames, IA) analyzed the ultrasound images and change in subcutaneous fat thickness was calculated as the difference between a measurement and the previous measurement. Three trained investigators determined BCS on a 5-point scale (in 0.25-point increments; Wildman et al., 1982) on the last day of the preliminary period and each treatment period.

\section{Sample Analysis}

Diet ingredients, orts, and fecal samples were dried at $55^{\circ} \mathrm{C}$ in a forced-air oven for $72 \mathrm{~h}$ for $\mathrm{DM}$ determination. Dried samples were ground with a Wiley mill (1 mm screen; Arthur H. Thomas, Philadelphia, PA). Feed ingredients, orts, and feces were analyzed for NDF, CP, and starch concentrations as described by Kammes and Allen (2012). The concentration of FA in feed ingredients, orts, and feces were determined as described by Lock et al. (2013). Indigestible NDF, used for estimating fecal mass and thus digestibility of nutrients (Cochran et al., 1986), was estimated as NDF after 240-h in vitro fermentation (Kammes and Allen, 2012) using rumen fluid from a nonlactating mature cow fed dry hay; flasks were reinoculated at $120 \mathrm{~h}$ to ensure a viable microbial population.

Individual milk samples were analyzed for fat, true protein, and lactose concentration by mid-infrared spectroscopy (AOAC, 1990, method 972.160) by the Michigan Herd Improvement Association (Universal Lab Services, Lansing, MI). Yields of 3.5\% FCM, milk energy, and milk components were calculated using milk yield and component concentrations for each milking, summed for a daily total, and averaged for each collection period.

A single milk sample per period for each cow was used for analysis of FA composition. Milk samples were composited based on milk fat yield (d 24-28 of each period). Milk lipids were extracted, and FAME were prepared and quantified using GLC according to our methods described previously (Lock et al., 2013). Yield of individual FA (g/d) in milk fat were calculated by using milk fat yield and FA concentration to determine yield on a mass basis using the molecular weight of each FA while correcting for glycerol content and other milk lipid classes (Piantoni et al., 2013).

\section{Plasma Metabolites and Hormones}

All plasma samples were analyzed in duplicate with a coefficient of variation of $<5 \%$ between duplicates. Commercial kits were used to determine plasma concentrations of NEFA [NEFA-HR (2) kit; Wako Chemicals, Richmond, VA] and triglycerides (TAG; L-Type Triglyceride M kit; Wako Chemicals, Richmond, VA). Insulin was measured with a bovine insulin ELISA using a solid phase 2-site enzyme immunoassay (Mercodia, Uppsala, Sweden). Glucose was quantified using a glucose oxidase method (PGO Enzyme Product No. P7119; Sigma Chemical Co., St. Louis, MO).

\section{Energy Partitioning Calculations}

Energy partitioning was determined during treatment periods using weekly milk samples taken from 4 consecutive milkings and analyzed for fat, protein, and lactose concentrations (Universal Lab Services), BW measurements 3 times per week following the morning milking, and BCS determined by 3 trained investigators on a 5-point scale (in 0.25 point increments; Wildman et al., 1982) on the last day of each period. Data were used to calculate milk energy output, metabolic BW, and body tissue gain throughout treatment periods.

Milk energy output (Mcal/d) was calculated according to NRC (2001) with an adjustment in the coefficient to account for the difference between $\mathrm{CP}$ and true protein:

$$
\begin{gathered}
\text { Milk energy output }(\mathrm{Mcal} / \mathrm{d})=[9.29 \times \text { fat }(\mathrm{kg}) \\
+5.63 \times \text { true protein }(\mathrm{kg})+3.95 \times \text { lactose }(\mathrm{kg})]
\end{gathered}
$$


where each component was based on the average output of a cow during the 28-d period. Metabolic BW $(\mathrm{MBW})$ was estimated as $\mathrm{BW}^{0.75}$, where $\mathrm{BW}$ was the mean BW for a cow during the 28 -d period. Mean daily BW change $(\mathrm{kg} / \mathrm{d})$ was calculated for each cow within period by linear regression after 2 iterations of removing outliers. Energy expended for body tissue gain (Mcal/d) was estimated according to NRC (2001):

$$
\begin{gathered}
\text { Body tissue gain }(\mathrm{Mcal} / \mathrm{d})= \\
{[(2.88+1.036 \times \mathrm{BCS}) \times \Delta \mathrm{BW}],}
\end{gathered}
$$

where BCS was the average BCS for a cow during a 28-d period.

Energy concentration of the diet was calculated using 2 methods for individual cows for each treatment: (1) based on nutrient digestibility using indigestible NDF as the internal marker and calculated using equations (NRC, 2001) according to Harvatine and Allen (2006); and (2) based on the sum of milk energy output, maintenance energy calculated from MBW, and body energy gain divided by DMI for each cow on each diet according to Boerman et al. (2015).

Energy partitioning (\%) was estimated based on observed performance:

$\%$ to milk, maintenance, or body tissue $=$

[milk energy output, $0.08 \times \mathrm{MBW}$, or body tissue

$$
\begin{gathered}
\text { gain } /(\text { milk energy output }+0.08 \times \mathrm{MBW} \\
+ \text { body tissue gain }) \times 100]
\end{gathered}
$$

where $\%$ to milk, maintenance, or body tissue is the percent of energy partitioned to milk production, maintenance requirement, or body tissue gain, respectively.

\section{Statistical Analysis}

Two cows were removed from analysis; one cow developed a displaced abomasum during the first period and another cow developed mastitis during the second period. Therefore, all results are from the 30 remaining cows. All data were analyzed using the fit model procedure of JMP (version 10; SAS Institute, Cary, NC). Data were analyzed using the following model:

$$
\begin{aligned}
\mathrm{Y}_{\mathrm{ijk}}= & \mu+\mathrm{C}_{\mathrm{i}}+\mathrm{P}_{\mathrm{j}}+\mathrm{T}_{\mathrm{k}}+\text { pMilk } \\
& + \text { pMilk } \times \mathrm{T}_{\mathrm{k}}+\mathrm{e}_{\mathrm{ijk}},
\end{aligned}
$$

where $\mathrm{Y}_{\mathrm{ijk}}=$ dependent variable, $\mu=$ overall mean, $\mathrm{C}_{\mathrm{i}}$ $=$ random effect of cow ( $\mathrm{i}=1$ to 30$), \mathrm{P}_{\mathrm{j}}=$ fixed effect of period $(\mathrm{j}=1$ or 2$), \mathrm{T}_{\mathrm{k}}=$ fixed effect of treatment $(\mathrm{k}$ $=1$ or 2 ), pMilk = covariate of preliminary milk yield, and pMilk $\times \mathrm{T}_{\mathrm{k}}=$ interaction between preliminary milk yield and treatment, and $\mathrm{e}_{\mathrm{ijk}}=$ the random error. The interaction between period and treatment was initially included in the model and removed because it was not significant $(P>0.20)$. Likewise, the quadratic effect of preliminary milk yield and the interaction between treatment and the quadratic effect of preliminary milk yield were initially included in the model and removed because they were not significant $(P>0.20)$. The pMilk and pMilk $\times \mathrm{T}_{\mathrm{k}}$ terms were removed from the model when $P>0.20$ for the interaction term. Main effects were declared significant at $P \leq 0.05$, and tendencies were declared at $P \leq 0.10$. Interactions were declared significant at $P \leq 0.10$, and tendencies were declared at $P \leq 0.15$. All data are expressed as least squares means and standard error of the means, unless otherwise specified.

\section{RESULTS}

\section{Diets}

Treatment diets differed in NDF, FA, and starch concentration and, to a lesser extent, $\mathrm{CP}$ concentration (Table 1). The HFF diet contained 33\% NDF, $20 \%$ forage NDF, $16 \%$ starch, and $5.4 \% \mathrm{FA}$, whereas the HS diet contained $25 \%$ NDF, $18 \%$ forage NDF, $33 \%$ starch, and $3.2 \%$ FA (Table 1). Treatments contained similar amounts of 18-carbon dietary FA; however, HFF contained an additional 2.2\% DM of 16-carbon dietary FA from the palmitic acid-enriched fat supplement.

\section{Production Variables}

The HFF treatment reduced milk yield by $1.3 \mathrm{~kg} / \mathrm{d}$ $(P<0.05$; Table 2$)$ with a trend for reduced DMI of 0.5 $\mathrm{kg} / \mathrm{d}(P=0.10)$ compared with HS. High-producing cows had increased DMI on the HFF treatment whereas lower-producing cows had reduced DMI on HFF compared with HS (interaction, $P<0.05$ ). The HFF treatment increased $3.5 \% \mathrm{FCM}(P<0.05)$ because of a $7.7 \%$ increase in fat yield of $\sim 130 \mathrm{~g} / \mathrm{d}(P<0.001)$. The HFF treatment increased milk fat concentration $(P<$ 0.001 ), whereas HFF decreased milk protein yield by $\sim 100 \mathrm{~g} / \mathrm{d}$ and milk fat concentration (both $P<0.001$ ) compared with HS. The HFF treatment increased milk energy output measured the last $5 \mathrm{~d}$ of each period by $0.9 \mathrm{Mcal} / \mathrm{d}(P<0.01)$. The HFF treatment increased milk-to-feed ratio (ECM/DMI) by $3 \%(P=0.02)$ compared with HS. Lower producing cows had an increased milk-to-feed ratio on HFF with similar feed efficiency for higher producing cows (interaction, $P=0.06$ ). 
Table 2. Dry matter intake, milk production, milk components, and feed efficiency for cows fed treatment diets $(\mathrm{n}=30)^{1}$

\begin{tabular}{|c|c|c|c|c|}
\hline \multirow[b]{2}{*}{ Item } & \multicolumn{2}{|c|}{ Treatment $^{2}$} & \multirow[b]{2}{*}{ SEM } & \multirow{2}{*}{$\frac{P \text {-value }}{\text { Trt }}$} \\
\hline & $\mathrm{HFF}$ & HS & & \\
\hline$\overline{\mathrm{DMI}^{4}}$ & 26.9 & 27.4 & 0.38 & 0.10 \\
\hline \multicolumn{5}{|l|}{ Milk yield $(\mathrm{kg} / \mathrm{d})$} \\
\hline Milk & 45.8 & 47.1 & 1.44 & 0.02 \\
\hline $3.5 \% \mathrm{FCM}^{5}$ & 49.1 & 47.6 & 1.59 & 0.03 \\
\hline \multicolumn{5}{|l|}{ Milk components } \\
\hline Fat $(\mathrm{kg} / \mathrm{d})$ & 1.81 & 1.68 & 0.06 & $<0.001$ \\
\hline Fat $(\%)$ & 3.95 & 3.58 & 0.09 & $<0.001$ \\
\hline Protein $(\mathrm{kg} / \mathrm{d})$ & 1.34 & 1.44 & 0.04 & $<0.001$ \\
\hline Protein $(\%)$ & 2.93 & 3.07 & 0.03 & $<0.001$ \\
\hline Lactose $(\mathrm{kg} / \mathrm{d})$ & 2.22 & 2.31 & 0.06 & 0.001 \\
\hline Lactose $(\%)$ & 4.85 & 4.92 & 0.03 & 0.001 \\
\hline Milk energy $^{6}(\mathrm{Mcal} / \mathrm{d})$ & 33.3 & 32.4 & 1.00 & 0.009 \\
\hline $\mathrm{ECM}^{7} / \mathrm{DMI}^{4}$ & 1.78 & 1.73 & 0.02 & 0.02 \\
\hline
\end{tabular}

${ }^{1}$ Samples and data for production variables collected during the last $5 \mathrm{~d}$ of each treatment period (d 24 to 28).

${ }^{2}$ Treatments were either a high-fiber, high-fat diet (HFF) containing a 50:50 ratio of forage to concentrate containing a C16:0-enriched FA supplement at 2.5\% of diet DM or a high-starch diet (HS) containing a 40:60 ratio of forage to concentrate containing a mixture of dry ground and high-moisture corn.

${ }^{3} P$-value associated with treatment differences (HFF vs. HS; Trt).

${ }^{4}$ Significant preliminary milk by treatment interaction; DMI $(P=0.04)$ and ECM/DMI $(P=0.06)$.

${ }^{5} 3.5 \% \mathrm{FCM}=[(0.4324 \times \mathrm{kg}$ of milk $)+(16.216 \times \mathrm{kg}$ of milk fat $)]$.

${ }^{6}$ Milk energy $=\mathrm{kg}$ of milk $\times[(0.0929 \times$ milk fat $\%)+(0.0563 \times$ milk protein $\%)+(0.0395 \times$ milk lactose $\%)]$.

${ }^{7} \mathrm{ECM}=[(0.327 \times \mathrm{kg}$ of milk $)+(12.95 \times \mathrm{kg}$ of milk fat $)+(7.20 \times \mathrm{kg}$ of milk protein $)]$.

\section{Body Composition}

The HFF treatment reduced BW $(P=0.01$; Table $3)$ and BCS $(P<0.001)$ compared with HS. The HFF treatment reduced change in BW by $\sim 13 \mathrm{~kg}$ compared with HS, over the 28-d treatment periods. Cows on the HFF treatment maintained BCS over the 28-d treatment periods, whereas cows on the HS treatment increased BCS by $\sim 0.25$ points $(P<0.001)$. Change in BCS was further evaluated by measuring subcutaneous fat thickness over the rump and 12th intercostal space at the end of periods. The HFF treatment reduced both measurements $(P<0.05)$, with a difference of $0.78 \mathrm{~mm}$ over the rump and $0.54 \mathrm{~mm}$ over the 12 th intercostal space between the 2 treatments.

\section{Calculated Energy Values and Partitioning}

Throughout treatment periods, the HFF treatment increased milk energy output $(P=0.05$; Table 3$)$ and decreased energy used for body tissue gain $(P<0.001)$ compared with HS. The HFF treatment increased the percentage of energy partitioned toward milk (72.8 vs. $67.9 \% ; P<0.001)$ and reduced the percentage of energy partitioned toward body tissue gain (4.03 vs. 10.1\%; $P<0.01$ ). Using cow performance data to calculate dietary energy of treatment diets indicated that similar energy concentrations were achieved for HFF versus HS (1.78 vs. $1.79 \mathrm{Mcal} / \mathrm{kg}$ of DM; $P=0.64$; Table 3$)$. How- ever, using digestible nutrient data to calculate dietary energy of treatment diets indicated $\sim 1 \%$ higher energy concentration for HFF versus HS (1.64 vs. $1.62 \mathrm{Mcal} /$ $\mathrm{kg}$ of DM; $P<0.01 ;$ Table 3$)$.

\section{Plasma Metabolites and Hormones}

We detected no differences in plasma glucose concentrations between treatments $(P=0.14$; Table 4$)$. However, the HFF treatment reduced insulin concentration in plasma by $27 \%(P<0.001)$. Higher-producing cows on the HFF treatment had reduced plasma insulin concentration compared with HS with similar insulin concentrations for lower producing cows (interaction, $P=0.06$; Figure 1). The HFF treatment increased the plasma concentrations of both NEFA and TAG (40 and $11 \%$, respectively; both $P<0.001$; Table 4 ).

\section{Digestibility}

The HFF treatment reduced DM digestibility $(P<$ $0.05)$ with no differences in starch digestibility $(P=$ 0.39 , Table 5). The HFF treatment increased digestibility of NDF and CP (both $P<0.001$ ). However, the HFF treatment tended to reduce total FA $(P=$ $0.06)$ and 16 -carbon FA digestibility $(P=0.07)$, but increased 18-carbon FA digestibility $(P<0.01)$ compared with HS. Increasing total FA intake did not affect FA digestibility $\left(\mathrm{R}^{2}=0.001 ; P=0.80\right.$; Figure 2$)$ between 
Table 3. Body weight, BCS, and change in subcutaneous fat thickness measurements and calculated energy values for cows fed treatment diets $(\mathrm{n}=30)^{1}$

\begin{tabular}{|c|c|c|c|c|}
\hline \multirow[b]{2}{*}{ Variable } & \multicolumn{2}{|c|}{ Treatments $^{2}$} & \multirow[b]{2}{*}{ SEM } & \multirow{2}{*}{$\frac{P \text {-value }}{3}$} \\
\hline & $\mathrm{HFF}$ & HS & & \\
\hline$\overline{\mathrm{BW}^{4}}$ & 678 & 685 & 14.8 & 0.01 \\
\hline $\mathrm{BCS}^{4}$ & 3.07 & 3.20 & 0.09 & $<0.001$ \\
\hline Change in BW (kg/d) & 0.33 & 0.78 & 0.10 & 0.003 \\
\hline Change in BCS (pt/28 d) & -0.01 & 0.24 & 0.03 & 0.001 \\
\hline Change in rump fat $(\mathrm{mm} / 28 \mathrm{~d})$ & -0.41 & 0.37 & 0.22 & 0.04 \\
\hline Change in rib fat $(\mathrm{mm} / 28 \mathrm{~d})$ & -0.08 & 0.46 & 0.14 & 0.04 \\
\hline \multicolumn{5}{|l|}{ Calculated energy values } \\
\hline Apparent $\mathrm{NE}_{\mathrm{L}}$ of $\operatorname{diet}^{5}(\mathrm{Mcal} / \mathrm{kg})$ & 1.64 & 1.62 & 0.01 & 0.003 \\
\hline Apparent $\mathrm{NE}_{\mathrm{L}}$ of $\operatorname{diet}^{6}(\mathrm{Mcal} / \mathrm{kg})$ & 1.78 & 1.79 & 0.02 & 0.64 \\
\hline Milk (Mcal/d) & 32.8 & 32.6 & 1.05 & 0.05 \\
\hline Body energy gain (Mcal/d) & 1.95 & 4.90 & 0.58 & 0.001 \\
\hline Maintenance (Mcal/d) & 10.6 & 10.7 & 0.17 & 0.02 \\
\hline \multicolumn{5}{|l|}{ Partitioning (\% energy intake) } \\
\hline Milk & 72.8 & 67.9 & 1.11 & $<0.001$ \\
\hline Body tissue gain & 4.03 & 10.1 & 1.16 & 0.001 \\
\hline Maintenance & 23.2 & 22.0 & 0.43 & 0.01 \\
\hline \multicolumn{5}{|c|}{${ }^{1}$ Based on animal performance throughout the $28 \mathrm{~d}$ periods unless otherwise stated. } \\
\hline \multirow{4}{*}{\multicolumn{5}{|c|}{$\begin{array}{l}{ }^{2} \text { Treatments were either a high-fiber, high-fat diet (HFF) containing a } 50: 50 \text { ratio of forage to concentrate } \\
\text { containing a C16:0-enriched FA supplement at } 2.5 \% \text { of diet DM or a high-starch diet (HS) containing a } 40: 60 \\
\text { ratio of forage to concentrate containing a mixture of dry ground and high-moisture corn. } \\
{ }^{3} \mathrm{P} \text {-value associated with treatment differences (HFF vs. HS; Trt). } \\
{ }^{4} \text { Mean throughout the } 28 \text {-d period. } \\
{ }^{5} \text { From digestibility equations (NRC, } 2001 \text { ) according to Harvatine and Allen (2006) based on nutrient digest- } \\
\text { ibility results collected during the last } 5 \text { d of each treatment period (Table 5). }\end{array}$}} \\
\hline & & & & \\
\hline & & & & \\
\hline & & & & \\
\hline \multicolumn{5}{|c|}{$\begin{array}{l}{ }^{6} \text { From the sum of milk energy output, maintenance energy calculated from metabolic BW, and body energy } \\
\text { gain divided by DMI for each cow on each diet throughout the } 28 \text {-d period. }\end{array}$} \\
\hline
\end{tabular}

approximately 500 to $1,900 \mathrm{~g} / \mathrm{d}$ of total FA intake. Consequently, we observed a positive linear relationship between total FA intake and total FA absorbed $\left(\mathrm{R}^{2}=\right.$ 0.94; $P<0.001$; Figure 3) up to approximately 1,900 $\mathrm{g} / \mathrm{d}$ of intake of total FA.

\section{Milk FA}

The concentration of FA in milk fat according to source $(<16$ carbon FA from de novo synthesis in the mammary gland, $>16$ carbon FA originating from extraction from plasma, and 16-carbon FA originating from mixed sources) are shown in Table 6. Concentrations and yields of selected individual FA are shown in Supplemental Tables S1 and S2, respectively (http:// dx.doi.org/10.3168/jds.2015-9467). Compared with HS, the HFF treatment reduced the concentration of de novo synthesized and preformed milk FA (both $P<$ 0.001 ) and increased milk FA derived from both sources (16-carbons in length; $P<0.001$; Table 6 ) primarily through an increased concentration of C16:0 in milk $(P$ $<0.001$; data in Supplemental Tables S1 and S2). The large increase in C16:0 caused shifts in relative proportions of de novo and preformed milk FA. In particular, the HFF treatment increased $\mathrm{C} 4: 0$ in milk fat $(P<$ 0.001 ) and decreased milk FA from 6 to 14 carbons in length (all $P<0.001$; data in Supplemental Tables S1 and S2). Compared with HS, the HFF treatment reduced the concentration of trans-10 C18:1 $(P=0.01$; data in Supplemental Tables S1 and S2).

On a yield basis, we observed no effect of treatment on the yield of preformed milk FA $(P=0.78$; Table 6$)$. The HFF treatment decreased the yield of de novo synthesized milk FA by $58 \mathrm{~g} / \mathrm{d}(P<0.001)$. The reduction

Table 4. Plasma concentrations of glucose, insulin, NEFA, and triglycerides (TAG) for cows fed treatment diets $(n=30)^{1}$

\begin{tabular}{lccrcc}
\hline & \multicolumn{2}{c}{ Treatment $^{2}$} & & $P^{2}$-value $^{3}$ \\
\cline { 2 - 3 } Variable & HFF & HS & & SEM & TRT \\
\hline Glucose $(\mathrm{mg} / \mathrm{dL})$ & 63.3 & 64.8 & 0.73 & 0.14 \\
Insulin $^{4}(\mu \mathrm{g} / \mathrm{L})$ & 0.76 & 1.01 & 0.05 & $<0.001$ \\
NEFA $(\mu \mathrm{Eq} / \mathrm{L})$ & 135 & 96.7 & & 3.80 & $<0.001$ \\
TAG $(\mathrm{mg} / \mathrm{dL})$ & 11.2 & 10.1 & & 0.29 & $<0.001$ \\
\hline
\end{tabular}

${ }^{1}$ Samples for plasma measurements were collected during the last $5 \mathrm{~d}$ of each treatment period (d 24 to 28).

${ }^{2}$ Treatments were either a high fiber and fat diet (HFF) containing a 50:50 ratio of forage to concentrate containing a C16:0-enriched FA supplement at $2.5 \%$ of diet DM or a high starch diet (HS) containing a 40:60 ratio of forage to concentrate containing a mixture of dry ground and high moisture corn.

${ }^{3} P$-value associated with treatment differences (HFF vs. HS; Trt).

${ }^{4}$ Significant linear preliminary milk by treatment interaction; $P=0.06$. 
Table 5. Apparent total-tract digestibilities of nutrients for cows fed treatment diets $(\mathrm{n}=30)^{1}$

\begin{tabular}{lcccc}
\hline & \multicolumn{2}{c}{ Treatment $^{2}$} & & $P^{2}$-value \\
\cline { 2 - 3 } \cline { 5 - 5 } Nutrient & HFF & HS & SEM & Trt \\
\hline DM & 64.2 & 65.4 & 0.38 & 0.04 \\
NDF & 46.9 & 35.1 & 0.80 & $<0.001$ \\
CP & 69.2 & 66.5 & 0.44 & $<0.001$ \\
Starch & 94.8 & 95.0 & 0.23 & 0.39 \\
FA & 69.9 & 71.8 & 1.02 & 0.06 \\
16 Carbon & 63.6 & 65.8 & 0.99 & 0.07 \\
18 Carbon & 77.6 & 74.3 & 1.13 & 0.001 \\
\hline
\end{tabular}

${ }^{1}$ Samples for digestibility measurements were collected during the last $5 \mathrm{~d}$ of each treatment period (d 24 to 28 ).

${ }^{2}$ Treatments were either a high-fiber, high-fat diet (HFF) containing a 50:50 ratio of forage to concentrate containing a C16:0-enriched FA supplement at $2.5 \%$ of diet DM or a high-starch diet (HS) containing a 40:60 ratio of forage to concentrate containing a mixture of dry ground and high-moisture corn.

${ }^{3} P$-value associated with treatment differences (HFF vs. HS; Trt).

in C14:0 and cis-9 C14:1 accounted for almost half of the difference in de novo FA yield between the HFF and HS treatments (both $P<0.001$; data in Supplemental Tables S1 and S2). The HFF treatment increased the yield of 16 -carbon milk FA by $179 \mathrm{~g} / \mathrm{d}(P<0.001$; Table 6$)$ with $\sim 175 \mathrm{~g}$ coming from $\mathrm{C} 16: 0(P<0.001$; data in Supplemental Tables S1 and S2).

\section{Pearson Correlation Coefficients}

We used Pearson correlation coefficients to assess relationships between variables (Table 7). Milk fat yield was negatively correlated with insulin concentration $(P$ $<0.01)$, plasma glucose concentration $(P<0.01)$, and plasma TAG concentration $(P<0.05)$. Milk fat concentration was negatively correlated with the concentration of trans-10 C18:1 in milk fat $(P<0.001)$. Change in BCS was positively correlated with plasma insulin concentration $(P<0.01)$, negatively correlated with plasma NEFA concentration $(P<0.001)$, and weakly positively correlated with the concentration of trans-10 C18:1 in milk fat $(P=0.09)$.

\section{DISCUSSION}

Feeding diets that differ in lipogenic and glucogenic nutrients has been shown to alter energy partitioning toward milk production or adipose tissue in early- (van Knegsel et al., 2007a) and established-lactation cows (Grum et al., 1996). van Knegsel et al. (2007a) fed diets differing in NDF, FA, and starch concentrations and observed no effect on milk yield or milk protein yield. However, cows fed the lipogenic (higher fiber and FA) diet increased milk fat concentration and yield, result-

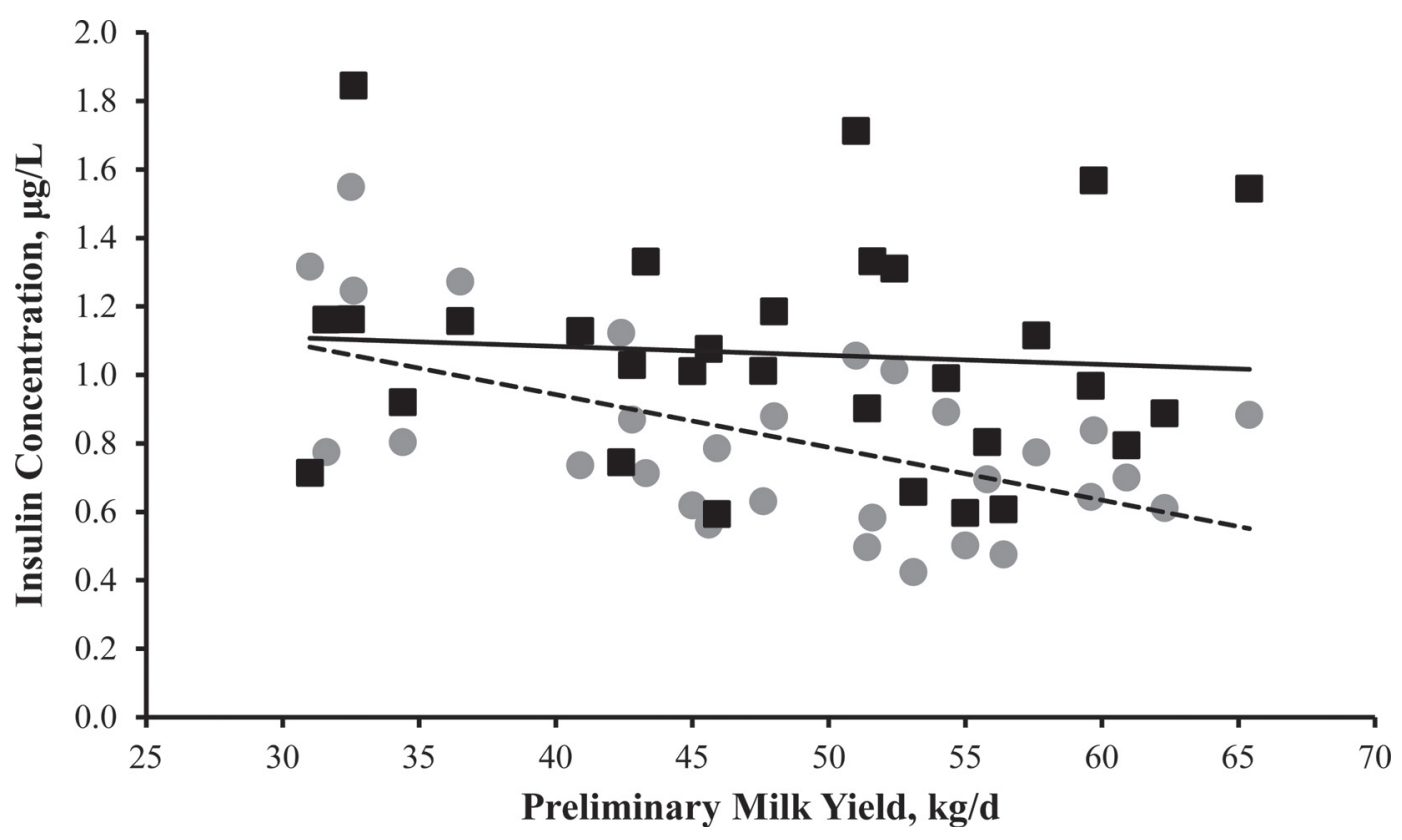

Figure 1. Relationship between preliminary milk yield $(\mathrm{kg} / \mathrm{d})$ and plasma insulin concentration $(\mu \mathrm{g} / \mathrm{L})$ of cows fed treatment diets $(\mathrm{n}=$ 30). Treatments were either a high-fiber, high-fat diet (HFF) containing a 50:50 ratio of forage to concentrate containing a C16:0-enriched FA supplement at $2.5 \%$ of diet DM or a high-starch diet (HS) containing a 40:60 ratio of forage to concentrate containing a mixture of dry ground and high-moisture corn. Cows with gray circles with a dashed trend line were on the HFF treatment [insulin concentration $(\mu \mathrm{g} / \mathrm{L})=1.56-0.015$ $\times$ (preliminary milk yield $\mathrm{kg} / \mathrm{d}) ; \mathrm{R}^{2}=0.31$ ]. Cows with black squares with a solid trend line were on the HS treatment [insulin concentration $(\mu \mathrm{g} / \mathrm{L})=1.19-0.003 \times($ preliminary milk yield $\left.\mathrm{kg} / \mathrm{d}) ; \mathrm{R}^{2}=0.01\right]$. Linear preliminary milk yield by treatment interaction $P=0.06$. 
ing in increased milk energy output with a trend for reduced energy retained as body fat. Grum et al. (1996) compared a high-concentrate diet to a high-forage diet with added FA, both diets were similar in predicted energy content. The high-forage diet with added fat increased milk fat concentration and yield compared with the high-concentrate diet. Cows in both studies on the more glucogenic (higher starch) diet had reduced milk energy output due to reduced milk fat yield, with the additional energy presumably stored as adipose tissue. In our study, we also examined the effect of a lipogenic diet, compared with an isocaloric glucogenic diet, on milk production and energy partitioning to evaluate an alternative to a high-starch diet for high-producing mid-lactation dairy cows. Although we observed similar results, with the lipogenic diet increasing milk fat yield and partitioning a greater proportion of energy to milk energy, we were also able to quantify the difference in BW gain and subcutaneous fat thickness between the 2 treatments in 28 -d periods.

We observed an increase in lactose yield on the high-starch treatment, suggesting that this diet provided more glucose precursors for milk production. Increasing the starch concentration also may increase microbial protein production, thereby increasing milk protein yield, similar to results reported by Grum et al. (1996). Additionally, increases in insulin concentration are associated with increased milk protein yield and concentration (McGuire et al., 1995; Griinari et al., 1997; Mackle et al., 1999), perhaps due to the effects of insulin on the activation cascade for milk protein synthesis (Winkelman and Overton, 2013) or other unknown mechanisms. The HFF treatment increased milk fat yield through an increase in palmitic acid in milk fat, similar to results observed by Lock et al. (2013) and Piantoni et al. (2013); these studies substituted a palmitic acid source for soyhulls and diets were not isocaloric. Nonetheless, a similar milk fat yield response was also observed when a palmitic acid source replaced stearic acid in isocaloric diets (Rico et al., 2014). We chose to use a palmitic acid-enriched fat supplement in the HFF treatment because, as highlighted in the aforementioned studies, increasing dietary palmitic acid can increase milk fat yield and, therefore, milk energy output. It remains to be determined whether utilizing a fat supplement containing other FA to provide a similar dietary energy content would have resulted in the HFF treatment partitioning more dietary energy to milk

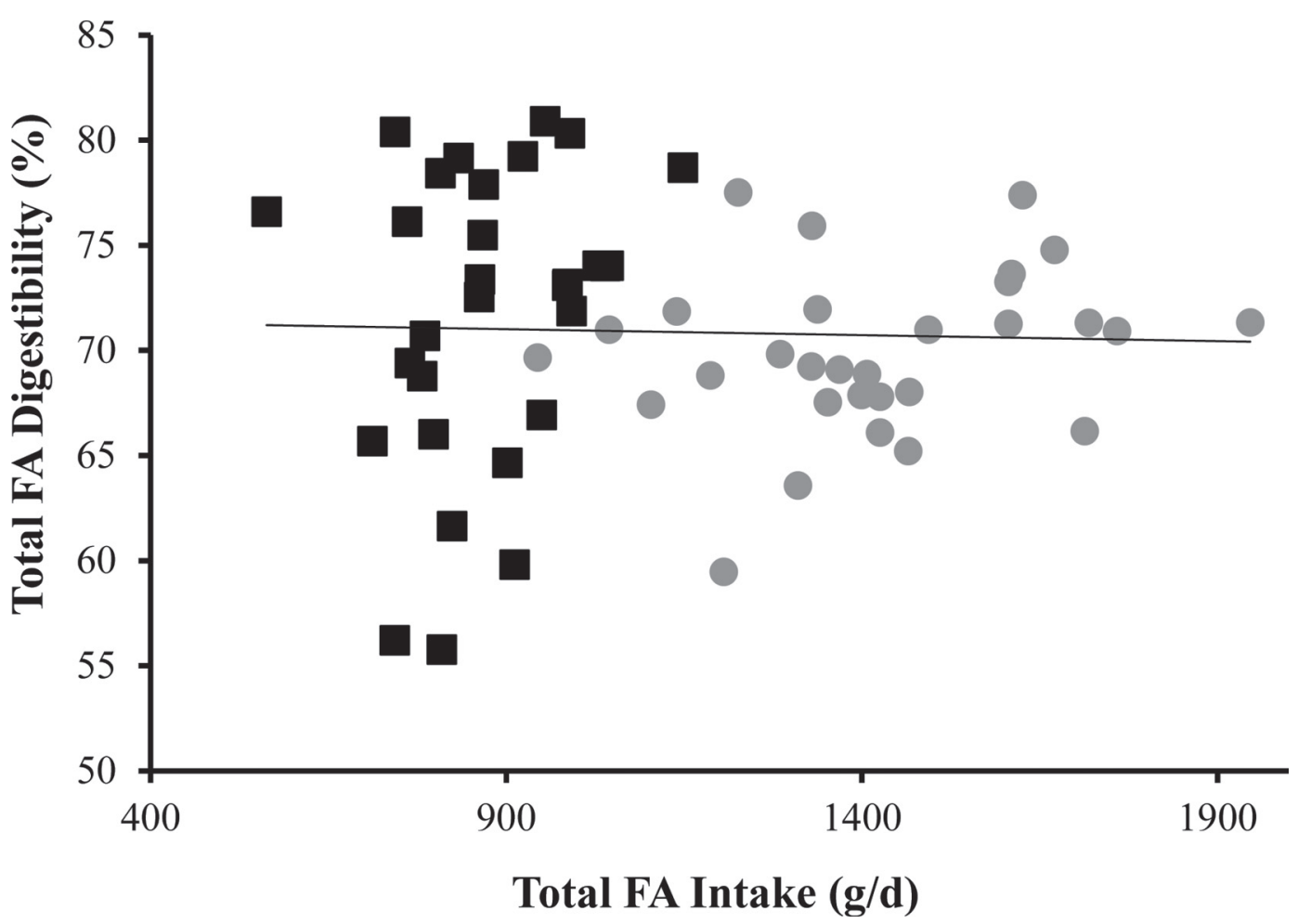

Figure 2. Relationship between total FA digestibility and total FA intake of cows fed treatment diets [total FA digestibility $(\%)=71.5-$ $0.001 \times($ total FA intake $\left.\mathrm{g} / \mathrm{d}) ; \mathrm{R}^{2}=0.001 ; P=0.81\right]$. Treatments were either a high-fiber, high-fat diet (HFF) containing a $50: 50$ ratio of forage to concentrate containing a C16:0-enriched FA supplement at 2.5\% of diet DM or a high-starch diet (HS) containing a 40:60 ratio of forage to concentrate containing a mixture of dry ground and high-moisture corn. Cows with black squares were on the HS treatment and cows with gray circles were on the HFF treatment $(\mathrm{n}=30)$. 


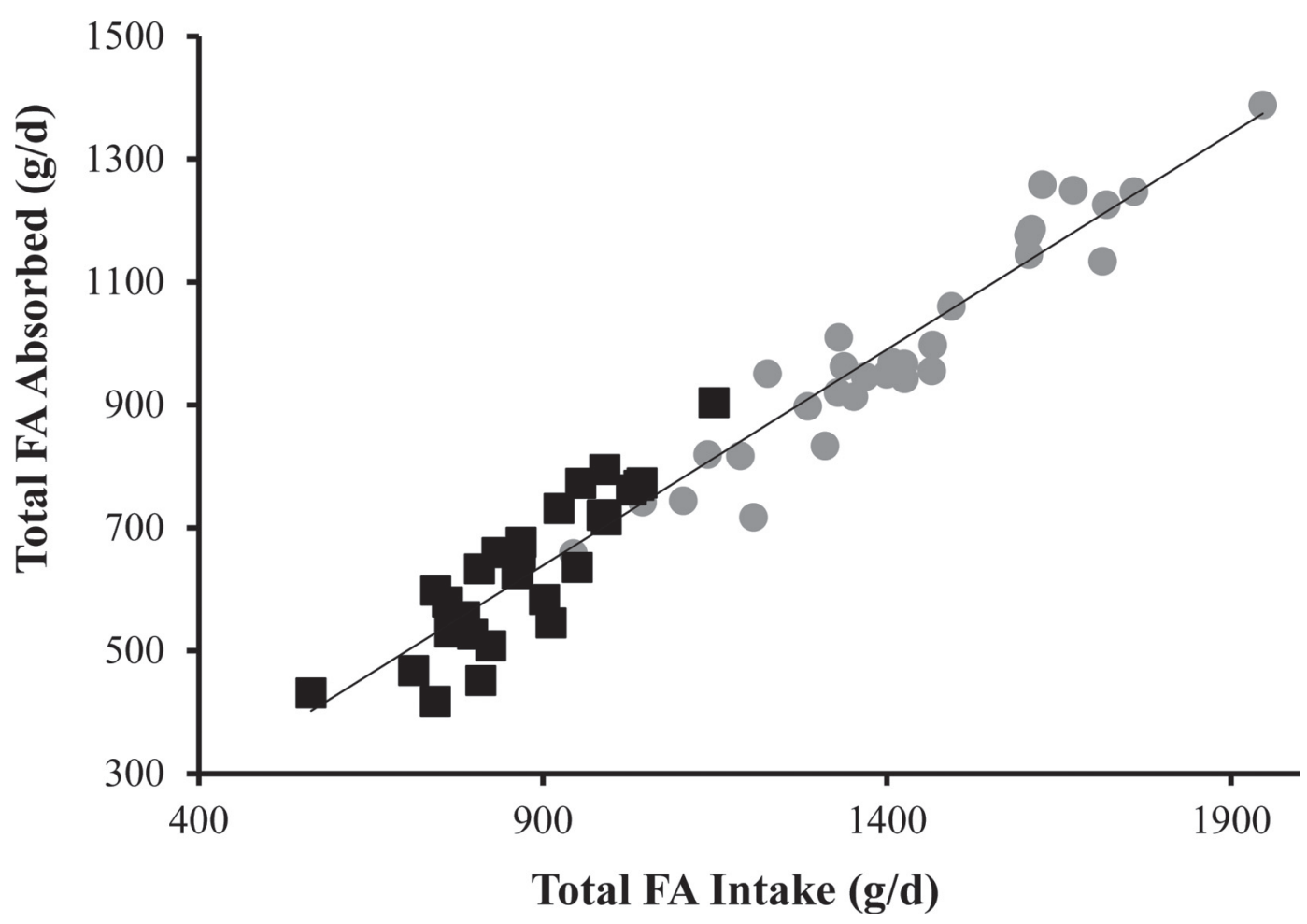

Figure 3. Relationship between total FA absorbed and total FA intake of cows fed treatment diets [total FA absorbed $(\mathrm{g} / \mathrm{d})=5.55+0.70$ $\times($ total FA intake $\mathrm{g} / \mathrm{d}) ; \mathrm{R}^{2}=0.94 ; P<0.0001$ ]. Treatments were either a high-fiber, high-fat diet (HFF) containing a 50:50 ratio of forage to concentrate containing a C16:0-enriched FA supplement at 2.5\% of diet DM or a high-starch diet (HS) containing a 40:60 ratio of forage to concentrate containing a mixture of dry ground and high-moisture corn. Cows with black squares were on the HS treatment, whereas cows with gray circles were on the HFF treatment $(\mathrm{n}=30)$.

versus body tissue gain when compared with the HS treatment.

We calculated dietary energy using 2 methods based on digestible nutrients or cow performance data. Results were relatively consistent across both methods, with the HFF treatment containing $~ 1 \%$ more dietary energy than the HS treatment when using digestible nutrient estimates of dietary energy. Similar apparent $\mathrm{NE}_{\mathrm{L}}$ concentrations of the diet and minimal differences in DMI were observed between the HFF and HS treatments, indicating that production differences and body composition differences were independent of apparent

Table 6. Fatty acid concentration and yield of milk FA by source for cows fed treatment diets $(\mathrm{n}=30)^{1}$

\begin{tabular}{|c|c|c|c|c|}
\hline \multirow[b]{2}{*}{ Summations of milk $\mathrm{FA}^{4}$} & \multicolumn{2}{|c|}{ Treatment $^{2}$} & \multirow[b]{2}{*}{ SEM } & \multirow{2}{*}{$\frac{P \text {-value }}{3}$} \\
\hline & HFF & HS & & \\
\hline \multicolumn{5}{|l|}{ FA concentration $(\mathrm{g} / 100 \mathrm{~g})$} \\
\hline De novo & 21.5 & 26.8 & 0.34 & $<0.001$ \\
\hline Mixed & 42.6 & 34.4 & 0.37 & $<0.001$ \\
\hline Preformed & 35.9 & 38.9 & 0.48 & $<0.001$ \\
\hline FA yield $(\mathrm{g} / \mathrm{d})$ & & & & $<0.001$ \\
\hline De novo & 367 & 425 & 18.66 & $<0.001$ \\
\hline Mixed & 723 & 544 & 26.25 & $<0.001$ \\
\hline Preformed & 603 & 606 & 18.29 & 0.78 \\
\hline
\end{tabular}

${ }^{1}$ Samples for milk FA were collected during the last $5 \mathrm{~d}$ of each treatment period (d 24 to 28 ).

${ }^{2}$ Treatments were either a high-fiber, high-fat diet (HFF) containing a 50:50 ratio of forage to concentrate containing a C16:0-enriched FA supplement at 2.5\% of diet DM or a high-starch diet (HS) containing a 40:60 ratio of forage to concentrate containing a mixture of dry ground and high-moisture corn.

${ }^{3} P$-value associated with treatment differences (HFF vs. HS; Trt).

${ }^{4}$ De novo $=$ milk FA $<16$ carbons in length; mixed $=$ milk FA 16 -carbons in length; preformed $=$ milk FA $>16$ carbons in length. 
$\mathrm{NE}_{\mathrm{L}}$ intake. Unsaturated $\mathrm{FA}$ have been shown to reduce DMI, presumably through the effects of cholecystokinin reducing gastric emptying and slowing passage rate from the rumen (Allen, 2000; Relling and Reynolds, 2007). However, saturated fat supplements have little to no effect on DMI (Allen, 2000). Although forage $\mathrm{NDF}$, which is highly negatively correlated with rumen fill and therefore reduced DMI, was higher for HFF, the additional wheat straw in the HS may have minimized the effects of differences in forage NDF.

A primary objective of our study was to determine treatment effects on energy partitioning. The HS treatment reduced energy partitioning to milk and increased energy partitioning to body tissue gain, similar to what is commonly observed during diet-induced MFD (Griinari and Bauman, 2006). Changes in BCS may be insensitive in short-term studies, and changes in BW may be confounded by differences in gut fill between diets (Harvatine et al., 2009). Therefore, we used 28-d periods as well as ultrasound images to measure subcutaneous fat thickness between the hide and musculature over the rump and the 12th intercostal space to determine changes in back fat thickness throughout a period. A change in $1 \mathrm{~mm}$ of backfat thickness is estimated to equate to $\sim 5 \mathrm{~kg}$ of body fat (Schröder and Staufenbiel, 2006). Whereas most work on adipose tissue deposits has been done in meat animals, the order of deposition is thought to be maintained in all species, with internal fat deposited first followed by subcutaneous, then interand intramuscular fat (Allen, 1976). Our measurements in the present study only allowed us to quantify subcutaneous fat differences rather than internal fat deposits that could also be affected by our dietary treatments. We observed that cows had increased BW and adipose tissue deposits when fed the HS treatment compared with the HFF treatment.

The changes in plasma metabolites and hormones we observed are similar to previous studies that fed supplemental fat (e.g., Grummer, 1991; Grum et al., 1996; Piantoni et al., 2013). Due to incomplete uptake of NEFA after hydrolysis of plasma TAG by lipoprotein lipase, increases in plasma NEFA concentration when feeding supplemental fat are common (Drackley, 1999). The increases that we observed are relatively small compared with NEFA concentrations in early lactation, and the mammary gland would not take up additional NEFA at the concentrations observed in our study (Miller et al., 1991). Additionally, elevated insulin concentrations will reduce plasma NEFA through inhibiting lipolysis or increasing lipogenesis (Vernon, 2005). Increased concentrations of TAG could result from higher levels of dietary FA increasing the supply of TAG-rich lipoproteins available in circulation. We did not expect changes in glucose concentrations due to the regulatory role of insulin and the glucogenic role of the liver in dairy cattle (Aschenbach et al., 2010). However, insulin concentrations were significantly higher for the HS treatment, in agreement with studies that altered dietary starch concentration (Grum et al., 1996; van Knegsel et al., 2007b). The reduction in insulin concentration observed in higher-producing cows on the HFF treatment compared with HS treatment might be due to differences in glucose precursors supplied by the 2 treatments. We would expect greater glucose clearance

Table 7. Correlation coefficients between production variables, plasma insulin and metabolites, and milk FA for cows fed treatment diets (n $=30)$

\begin{tabular}{|c|c|c|c|c|c|c|c|c|c|}
\hline Item & $\begin{array}{c}\text { Milk fat } \\
\text { yield }(\mathrm{kg} / \mathrm{d})\end{array}$ & $\begin{array}{l}\text { Milk } \\
\text { fat \% }\end{array}$ & $\begin{array}{c}\text { Milk } \\
\text { yield }(\mathrm{kg} / \mathrm{d})\end{array}$ & $\triangle \mathrm{BCS}$ & $\begin{array}{l}\text { Insulin } \\
(\mu \mathrm{g} / \mathrm{L})\end{array}$ & $\begin{array}{l}\text { NEFA } \\
(\mu \mathrm{Eq} / \mathrm{L})\end{array}$ & $\begin{array}{l}\text { Glucose } \\
(\mathrm{mg} / \mathrm{dL})\end{array}$ & $\begin{array}{l}\text { Triglycerides } \\
(\mathrm{mg} / \mathrm{dL})\end{array}$ & $\begin{array}{c}\mathrm{C} 18: 1 \\
\text { trans- } 10^{1}\end{array}$ \\
\hline Milk fat yield & 1 & $\begin{array}{c}0.44^{2} \\
(<0.001)^{3}\end{array}$ & $\begin{array}{c}0.78 \\
(<0.001)\end{array}$ & $\begin{array}{c}-0.03 \\
(0.80)\end{array}$ & $\begin{array}{c}-0.35 \\
(0.006)\end{array}$ & $\begin{array}{c}0.08 \\
(0.56)\end{array}$ & $\begin{array}{c}-0.37 \\
(0.004)\end{array}$ & $\begin{array}{c}-0.29 \\
(0.02)\end{array}$ & $\begin{array}{c}-0.04 \\
(0.76)\end{array}$ \\
\hline Milk yield & & & 1 & $\begin{array}{c}0.08 \\
(0.54)\end{array}$ & $\begin{array}{c}-0.32 \\
(0.02)\end{array}$ & $\begin{array}{r}-0.07 \\
(0.60)\end{array}$ & $\begin{array}{c}-0.27 \\
(0.04)\end{array}$ & $\begin{array}{l}-0.39 \\
(0.002)\end{array}$ & $\begin{array}{c}0.28 \\
(0.03)\end{array}$ \\
\hline NEFA & & & & & & 1 & $\begin{array}{c}-0.09 \\
(0.51)\end{array}$ & $\begin{array}{c}0.31 \\
(0.02)\end{array}$ & $\begin{array}{c}-0.12 \\
(0.35)\end{array}$ \\
\hline Glucose & & & & & & & 1 & $\begin{array}{c}0.07 \\
(0.62)\end{array}$ & $\begin{array}{c}0.13 \\
(0.31)\end{array}$ \\
\hline TAG & & & & & & & & 1 & $\begin{array}{c}-0.06 \\
(0.63)\end{array}$ \\
\hline
\end{tabular}

${ }^{1}$ Concentration of trans-10 C18:1 in milk fat.

${ }^{2}$ The Pearson correlation coefficient of the linear relationship between 2 variables.

${ }^{3}$ The $P$-value associated with the linear relationship between 2 variables. 
in high-producing cows and, therefore, reduced insulin concentrations compared with lower-producing cows. However, the HS treatment presumably provided more glucose precursors or glucose, thereby increasing insulin production to clear the additional glucose from circulation compared with when high-producing cows were on the HFF treatment.

Whereas trans-10 C18:1 concentrations are elevated in milk fat during MFD, abomasal infusions of this FA had no effect on milk fat yield (Lock et al., 2007). However, a robust relationship exists between production of trans-10 C18:1 in the rumen and milk fat synthesis (e.g., Loor et al., 2005; Shingfield et al., 2009). Thus, trans-10 C18:1 can serve as a marker for the specific FA isomers that directly inhibit milk fat synthesis (Bauman et al., 2011). We observed that concentrations of trans-10 C18:1 in milk fat were negatively correlated with milk fat concentration, similar to previous observations (Loor et al., 2005; Shingfield et al., 2009). In our study, concentrations of trans-10,cis-12 C18:2 in milk fat were below the limits of detection in most of the samples; however, trans-10 C18:1 is present at much greater concentrations in milk fat, and treatment differences indicate alternative biohydrogenation for the HS treatment. Reduced rumen $\mathrm{pH}$ is a risk factor for MFD, with trans-10 intermediate production increasing with lowered rumen pH (AbuGhazaleh et al., 2005). The reduction in $\mathrm{pH}$ possibly increases the lag phase of biohydrogenation and exacerbates the negative effects of PUFA on rumen bacteria (Maia et al., 2010). In our study, the increased concentration of starch in the HS treatment likely contributed to reduced rumen $\mathrm{pH}$ and favored alternative MFD-inducing biohydrogenation pathways. Harvatine et al. (2009) reported that during abomasal infusions of trans-10,cis-12 C18:2, a significant reduction in milk fat concentration and yield occurred because of the downregulation of lipogenic genes in mammary tissue. Conversely, a significant increase in the expression of lipogenic enzymes in adipose tissue occurred (Harvatine et al., 2009). Therefore, increases in trans-10,cis-12 C18:2 may result in repartitioning of energy by reducing milk fat output and increasing body fat reserves. Interestingly, we observed a positive correlation between the concentrations of trans-10 C18:1 in milk fat and change in BCS.

Corl et al. (2006) used a hyperinsulinemic-euglycemic clamp to increase insulin without changing glucose concentrations to assess the effect of increasing plasma insulin concentration on milk fat synthesis. Increasing insulin resulted in a marked reduction in preformed FA without any negative effects on de novo or mixed sources of milk FA, with a greater effect in early versus established lactation animals (Corl et al., 2006). Elevated insulin concentrations could partition circulating TAG into adipose instead of uptake by the mammary gland and reduce lipolysis from adipose tissues. However, injections of long-acting insulin did not reduce milk fat concentration or yield and shifted the FA profile with an increase in de novo synthesized milk FA and a reduction in preformed milk FA compared with a control in established-lactation dairy cattle (Winkelman and Overton, 2013). The reduction in preformed milk FA from these previous studies does not support our observations of increased insulin concentrations with the high-starch diet, yet no reduction in preformed milk FA compared with the high-fat diet. However, we observed that insulin concentrations were negatively correlated with milk fat yield, consistent with insulin potentially being a contributor to reduced milk fat with higherstarch diets. Insulin was also positively correlated with change in BCS. Potentially, injections of insulin or the use of a hyperinsulemic-euglycemic clamp may not be indicative of the long-term effects of increases in insulin due to changes in dietary nutrients.

In our study, we used relatively high-producing cows with high requirements of glucose. We therefore anticipated that the dietary treatment effects on milk fat yield and energy partitioning would be greater in later lactation cows at lower milk yield with reduced glucose requirements. The oversupply of glucose precursors may further increase insulin, due to the increase in insulin or insulin sensitivity as lactation progresses. Additionally, lower-producing cows may have increased concentrations of biohydrogenation intermediates associated with MFD, as observed by Bradford and Allen (2004). Both of these factors could exacerbate the effects of a highstarch diet compared with a high-fiber, high-fat diet on later-lactation dairy cows.

The reduction in de novo milk FA is typical of the trend we see when increasing palmitic acid in the diet with studies differing in their extent of response (Lock et al., 2013; Piantoni et al., 2013; Rico et al., 2014). Palmitic acid supplementation increases the yield of C4:0 while reducing the yield of $\mathrm{C} 6: 0$ to cis-9 C14:1 with longer-chain de novo synthesized FA having the largest reduction in FA yield (Rico et al., 2014).

Treatment had no effect on total-tract starch digestibility; however, we expect that differences in site of starch digestion might have occurred, with less ruminal starch digestibility and more intestinal starch digestibility with the HFF treatment (Firkins et al., 2001; Huntington et al., 2006). The HFF treatment increased NDF digestibility presumably because HFF contained soyhulls, an NDF source that is more highly digested than the NDF of the forages (especially wheat straw) in the HS diet. Even at high intakes of total FA we detected minimal treatment differences in FA digestibility and therefore observed a positive linear relationship 
between total FA absorbed and total FA intake. This is contrary to Piantoni et al. (2013), who reported total FA digestibility was reduced at higher intake of FA when feeding a 99\% palmitic acid-enriched FA supplement. Potentially, these differences in FA digestibility are due to differences in size and relative solubility of the fat supplements or other dietary differences. The current results are supported by our recent meta-analysis in which we observed that C16:0 digestibility was not affected by flow of C16:0 through the duodenum (Boerman et al., 2015).

Our aim was to evaluate the effect of isocaloric diets differing in lipogenic and glucogenic potential on energy partitioning. To achieve this, we were not able to simply replace one ingredient for another; thus, diets differed in NDF, starch, and FA, with much of the starch in the HS diet being from high-moisture corn. Based on how the diets were formulated, we expected to cause a greater reduction in milk fat yield. The HS treatment had what many would consider an acceptable milk fat concentration $(3.6 \%)$, yet we still observed differences in milk fat output and subcutaneous fat accumulation between the 2 treatments. We anticipate that a greater reduction in milk fat synthesis would have exacerbated these differences. The regulation of partitioning could be linked to increased insulin concentrations or production of biohydrogenation intermediates. However, in our study we were unable to separate the effects of insulin and MFD-inducing intermediates on partitioning; therefore, the mode of action is still unknown and warrants further examination.

\section{CONCLUSIONS}

Feeding diets differing in NDF, starch, and FA concentrations resulted in differences in energy partitioning in dairy cattle. A high-forage diet, supplemented with palmitic acid, increased milk fat yield, whereas a high-starch diet increased body fat gain. The differences in partitioning are likely from the combined effects of increasing plasma insulin concentrations and elevated ruminal biohydrogenation intermediates in the high-starch diet, favoring storage of nutrients as adipose over use for milk fat synthesis. The long-term implications of diets differing in their ability to partition energy warrant further investigation.

\section{ACKNOWLEDGMENTS}

We acknowledge C. L. Preseault, J. S. Liesman, J. E. Rico, Y. Sun, L. C. Nagengast, J. L. Garver, K. Spaans, and T. N. Bryant (all in the Department of Animal Science, Michigan State University) and the staff of the Michigan State University Dairy Cattle Field Laboratory for their assistance in this experiment, and Al Ames (NutriLinx, Burlington, VT) for donation of the C16:0-enriched FA supplement. This study was supported in part by Agriculture and Food Research Initiative Competitive Grant no. 2011-6800430340 from the USDA National Institute of Food and Agriculture (to MJV; Washington, DC) and Michigan State University AgBioResearch.

\section{REFERENCES}

AbuGhazaleh, A. A., M. B. Riley, E. J. Thies, and T. C. Jenkins. 2005. Dilution rate and $\mathrm{pH}$ effects on the conversion of oleic acid to trans C18:1 positional isomers in continuous culture. J. Dairy Sci. 88:4334-4341.

Allen, C. E. 1976. Cellularity of adipose tissue in meat animals. Fed. Proc. 35:2302-2307.

Allen, M. S. 2000. Effects of diet on short-term regulation of feed intake by lactating dairy cattle. J. Dairy Sci. 83:1598-1624.

AOAC. 1990. Official Methods of Analysis. 15th ed. AOAC International, Arlington, VA.

Aschenbach, J. R., N. B. Kristensen, S. S. Donkin, H. M. Hammon, and G. B. Penner. 2010. Gluconeogenesis in dairy cows: the secret of making sweet milk from sour dough. IUBMB Life 62:869-877.

Bauman, D. E. 2000. Regulation of nutrient partitioning during lactation: homeostasis and homeorhesis revisited. Pages 311-328 in Ruminant Physiology, Digestion, Metabolism, Growth and Reproduction. Proceedings of the 9th International Symposium on Ruminant Physiology. P. B. Cronje, ed. CABI Publishing, New York, NY.

Bauman, D. E., K. J. Harvatine, and A. L. Lock. 2011. Nutrigenomics, rumen-derived bioactive fatty acids, and the regulation of milk fat synthesis. Annu. Rev. Nutr. 31:299-319.

Boerman, J. P., S. B. Potts, M. J. VandeHaar, M. S. Allen, and A. L. Lock. 2015. Milk production responses to a change in dietary starch concentration vary by production level in dairy cattle. J. Dairy Sci. 98:4698-4706.

Bradford, B. J., and M. S. Allen. 2004. Milk fat responses to a change in diet fermentability vary by production level in dairy cattle. J. Dairy Sci. 87:3800-3807.

Cochran, R. C., D. C. Adams, J. D. Wallace, and M. L. Galyean. 1986. Predicting the digestibility of different diets with internal markers: Evaluation of four potential markers. J. Anim. Sci. 63:1476-1483.

Corl, B. A., S. T. Butler, W. R. Butler, and D. E. Bauman. 2006. Short communication: Regulation of milk fat yield and fatty acid composition by insulin. J. Dairy Sci. 89:4172-4175.

Drackley, J. K. 1999. Biology of dairy cows during the transition period: The final frontier? J. Dairy Sci. 82:2259-2273.

Firkins, J. L., M. L. Eastridge, N. R. St-Pierre, and S. M. Noftsger. 2001. Effects of grain variability and processing on starch utilization by lactating dairy cattle. J. Anim. Sci. 79:E218-E238.

Griinari, J. M., and D. E. Bauman. 2006. Milk fat depression: Concepts, mechanisms and management applications. Pages 389-409 in Ruminant Physiology Digestion, Metabolism and Impact of Nutrition on Gene Expression, Immunology and Stress. Wageningen Academic Publ., Wageningen, the Netherlands.

Griinari, J. M., M. A. McGuire, D. A. Dwyer, D. E. Bauman, D. M. Barbano, and W. A. House. 1997. The role of insulin in the regulation of milk protein synthesis in dairy cows. J. Dairy Sci. 80:2361-2371.

Grum, D. E., J. K. Drackley, L. R. Hansen, and J. D. Cremin Jr. 1996. Production, digestion, and hepatic lipid metabolism of dairy cows fed increased energy from fat or concentrate. J. Dairy Sci. 79:1836-1849

Grummer, R. R. 1991. Effect of feed on the composition of milk fat. J. Dairy Sci. 74:3244-3257. 
Harvatine, K. J., and M. Allen. 2006. Effects of fatty acid supplements on milk yield and energy balance of lactating dairy cows. J. Dairy Sci. 89:1081-1091.

Harvatine, K. J., J. W. Perfield, and D. E. Bauman. 2009. Expression of enzymes and key regulators of lipid synthesis is upregulated in adipose tissue during cla-induced milk fat depression in dairy cows. J. Nutr. 139:849-854.

Huntington, G. B., D. L. Harmon, and C. J. Richards. 2006. Sites, rates, and limits of starch digestion and glucose metabolism in growing cattle. J. Anim. Sci. 84:E14-E24.

Kammes, K. L., and M. S. Allen. 2012. Nutrient demand interacts with grass maturity to affect milk fat concentration and digestion responses in dairy cows. J. Dairy Sci. 95:5133-5148.

Lock, A. L., C. L. Preseault, J. E. Rico, K. E. DeLand, and M. S. Allen. 2013. Feeding a C16:0-enriched fat supplement increased the yield of milk fat and improved conversion of feed to milk. J. Dairy Sci. 96:6650-6659.

Lock, A. L., C. Tyburczy, D. A. Dwyer, K. J. Harvatine, F. Destaillats, Z. Mouloungui, L. Candy, and D. E. Bauman. 2007. Trans-10 octadecenoic acid does not reduce milk fat synthesis in dairy cows. J. Nutr. 137:71-76.

Loor, J. J., A. Ferlay, A. Ollier, M. Doreau, and Y. Chilliard. 2005. Relationship among trans and conjugated fatty acids and bovine milk fat yield due to dietary concentrate and linseed oil. J. Dairy Sci. 88:726-740.

Mackle, T. R., D. A. Dwyer, K. L. Ingvartsen, P. Y. Chouinard, J. M. Lynch, D. M. Barbano, and D. E. Bauman. 1999. Effects of insulin and amino acids on milk protein concentration and yield from dairy cows. J. Dairy Sci. 82:1512-1524.

Maia, M. R., L. C. Chaudhary, C. S. Bestwick, A. J. Richardson, N. McKain, T. R. Larson, I. A. Graham, and R. J. Wallace. 2010. Toxicity of unsaturated fatty acids to the biohydrogenating ruminal bacterium, Butyrivibrio fibrisolvens. BMC Microbiol. 10:52.

McGuire, M. A., J. M. Griinari, D. A. Dwyer, and D. E. Bauman 1995. Role of insulin in the regulation of mammary synthesis of fat and protein. J. Dairy Sci. 78:816-824.

Miller, P. S., B. L. Reis, C. C. Calvert, E. J. DePeters, and R. L. Baldwin. 1991. Relationship of early lactation and bovine somatotropin on nutrient uptake by cow mammary gland. J. Dairy Sci. 74:3800-3806.

NRC. 2001. Nutrient Requirements of Dairy Cattle. 7th rev. ed. Natl. Acad. Sci., Washington DC.

Piantoni, P., A. L. Lock, and M. S. Allen. 2013. Palmitic acid increased yields of milk and milk fat and nutrient digestibility across production level of lactating cows. J. Dairy Sci. 96:7143-7154.
Relling, A. E., and C. K. Reynolds. 2007. Feeding rumen-inert fats differing in their degree of saturation decreases intake and increases plasma concentrations of gut peptides in lactating dairy cows. J. Dairy Sci. 90:1506-1515.

Rico, J. E., M. S. Allen, and A. L. Lock. 2014. Compared with stearic acid, palmitic acid increased the yield of milk fat and improved feed efficiency across production level of cows. J. Dairy Sci. 97:1057-1066.

Roche, J. R., N. C. Figgens, J. K. Kay, M. W. Fisher, K. J. Stafford, and D. P. Berry. 2009. Invited review: Body condition score and its association with dairy cow productivity, health, and welfare. J. Dairy Sci. 92:5769-5801.

Schröder, U. J., and R. Staufenbiel. 2006. Invited review: Methods to determine body fat reserves in the dairy cow with special regard to ultrasonographic measurement of backfat thickness. J. Dairy Sci. 89:1-14

Shingfield, K. J., A. Sæbø, P.-C. Sæbø, V. Toivonen, and J. M. Griinari. 2009. Effect of abomasal infusions of a mixture of oxtadecenoic acids on milk fat synthesis in lactating cows. J. Dairy Sci. 92:4317-4329.

van Knegsel, A. T. M., H. van den Brand, J. Dijkstra, W. M. van Straalen, M. J. W. Heetkamp, S. Tamminga, and B. Kemp. 2007a. Dietary energy source in dairy cows in early lactation: Energy partitioning and milk composition. J. Dairy Sci. 90:1467-1476.

van Knegsel, A. T. M., H. van den Brand, E. A. M. Graat, J. Dijkstra, R. Jorritsma, E. Decuypere, S. Tamminga, and B. Kemp. 2007b. Dietary energy source in dairy cows in early lactation: Metabolites and metabolic hormones. J. Dairy Sci. 90:1477-1485.

Van Soest, P. J. 1963. Ruminant fat metabolism with particular reference to factors affecting low milk fat and feed efficiency: A review. J. Dairy Sci. 46:204-216.

Vernon, R. G. 2005. Lipid metabolism during lactation: A review of adipose tissue-liver interactions and the development of fatty liver. J. Dairy Res. 72:460-469.

Wildman, E. E., G. M. Jones, P. E. Wagner, and R. L. Bowman. 1982. A dairy cow body condition scoring system and its relationship to selected production characteristics. J. Dairy Sci. 65:495-501.

Winkelman, L. A., and T. R. Overton. 2013. Long-acting insulins alter milk composition and metabolism of lactating dairy cows. J. Dairy Sci. 96:7565-7577. 